\title{
Preparation and Optimization of PEG-PLGA Loaded with Vincristine Sulfate and its In vitro Release
}

WEN Jia-Gen ${ }^{1 \#, ~ G U O ~ T i n g t i n g ~}{ }^{1 \#}$, ZHU Hong-Yuan ${ }^{2}$, XIAO Yi-Yun ${ }^{1}, Z_{\text {ZHANG Xiu-Zhen }}{ }^{1}$, CHEN Guo ${ }^{1}$ and CHEN Yuxiang ${ }^{1 *}$

${ }^{1}$ School of Biological Sciences and Technology Central South University, Changsha 410078, P.R. China

${ }^{2}$ Merck Sharp \& Dohme, Changsha 410008, P.R. China

\#Who contributed equally to this work

\begin{abstract}
The aim of this study was to prepare the PEG-PLGA loaded with vincristine sulfate nanoparticles (VCR-loaded PEG-PLGA-NPs) and investigate its in vitro release properties. VCR-loaded PEG-PLGA-NPs were prepared by the modified double emulsion $\left(\mathrm{W}_{1} / \mathrm{O} / \mathrm{W}_{2}\right)$ method, and the main experimental factors influencing the characteristics of the nanoparticles were investigated and the preparation was optimized. The results showed that the physicochemical characteristics of VCR-loaded PEG-PLGA-NPs were affected by the polymer concentration, the ratio of internal water phase to oil phase, external water phase to oil phase and ultrasound time for the second time. VCR-loaded PEG-PLGA-NPs, with average particle size of $135.9 \mathrm{~nm}$, zeta potential of $-12.83 \mathrm{mV}$, encapsulation efficiency of $68.2 \%$ and drug loading of $8.34 \%$, were prepared under optimal conditions. The release experiments in vitro showed the VCR release from PEG-PLGA-NPs exhibited consequently sustained release for more than 13d, which was in accordance with Higuchi equation.
\end{abstract}

Keywords: PEG-PLGA; Vincristine sulfate; Modified double emulsion method; In vitro drug release

\section{Introduction}

Vincristine sulphate (VCR), a dimeric indole alkaloid isolated from the periwinkle plant Catheranthus roseus [1], is one of the most common chemotherapeutic drugs used for the treatment of several forms of malignancies [2,3]. It has been found to be active against the acute lymphoblastic leukemia, Hodgkin's disease, non-Hodgkin's lymphoma, neuroblastoma, breast cancer, etc [4,5]. Its antineoplastic effects are to interfere with microtubule assembly and induce tubulin selfassociation into coiled spiral aggregates during mitosis, thus inhibit division of cells [6,7]. Unfortunately, many tumor cells are not sensitive to VCR because of efflux from the tumor cells mediated by P-glycoprotein (Pgp), multidrug resistance-associated protein 1 (MRP1), MRP2 and MRP3 [8,9]. Meanwhile, VCR also has severe nervous system toxicity when administered systematically [10]. To improve the effectiveness and decrease the side effects of VCR, it is a potential approach to deliver VCR by targeting delivery system [11].

Recently biodegradable polymeric NPs for drug delivery have shown significant therapeutic potential [12-14]. Biodegradable polymers such as poly (d,l-lacticacid), poly (d,l-lactic-co-glycolic acid) and their co-polymers diblocked or multiblocked with PEG have been commonly used to form core-shell structured NPs to encapsulate a variety of therapeutic compounds. These NPs have a number of appealing features: their hydrophobic core is capable of carrying highly insoluble drugs with high loading capacity, while their hydrophilic shell provides steric protection and functional groups for surface modification [15].

In this study, biodegradable polymeric NPs made from polyethyleneglycol-modified poly (d,l-lactide-co-glycolide) (PEGPLGA-NPs), which have been extensively used as drug delivery systems for a variety of drugs were investigated for encapsulating VCR. Nanoparticles prepared from PEG-PLGA-NPs are being extensively investigated due to their controlled release, biodegradable and biocompatibility $[16,17]$. Several methods have been reported for the preparation of biodegradable polymer nanoparticles, such as solvent evaporation [18], nanoprecipitation [19] and salting-out [20]. Among these methods, the modified double emulsion solvent evaporation method is the most common used for the encapsulation of hydrophilic drug. VCR-loaded PEG-PLGA-NPs were prepared by the modified double emulsion $\left(\mathrm{W}_{1} / \mathrm{O} / \mathrm{W}_{2}\right)$ method, and the main experimental factors influencing the characteristics of nanoparticles were investigated and the preparation was optimized, which could provide the basis for the further research of the VCR-loaded-PEG-PLGA-NPs.

\section{Materials and Methods}

\section{Materials}

PEG-PLGA (PEG, Mw=2000 PLGA, Mw=35000 LA/DA 50:50) was purchased from ShanDong JiNan DaiGang Biotechnology Company; Vincristine (98.9\% purity) was purchased from Shanghai Institute of Materia Medica; poly vinyl alcohol (PVA 13000-23000, 87\%-89\% hydrolyze); Tween-80; F-68; acetone were of analytical grade.

\section{Preparation of PEG-PLGA-NPs}

PEG-PLGA nanoparticles loaded with VCR were prepared by a modified double emulsion (W1/O/W2) method. Briefly, a certain volume of the VCR solution as the internal water phase $(10 \mathrm{mg} /$ $\mathrm{ml}$, dissolved in ethanol) was added in the organic phase dissolved a certain amount of PEG-PLGA. Then, the mixture was ultrasound using probe sonication for a while to form the primary W1/O emulsion. This emulsion was transferred to an aqueous solution as the external

*Corresponding author: Dr. CHEN Yu-xiang, School of Biological Sciences and Technology Central South University, Changsha 410078, P.R. China, Tel:+86 731 84327971; E-mail: Chenyx008@yahoo.cn

Received September 20, 2011; Accepted October 24, 2011; Published October 26, 2011

Citation: Jia-Gen W, Tingting G, Hong-Yuan Z, Yi-Yun X, Xiu-Zhen Z, et al. (2011) Preparation and Optimization of PEG-PLGA Loaded with Vincristine Sulfate and its In vitro Release . J Bioequiv Availab 3: 211-214. doi:10.4172/jbb.1000088

Copyright: (c) 2011 Jia-Gen W, et al. This is an open-access article distributed under the terms of the Creative Commons Attribution License, which permits unrestricted use, distribution, and reproduction in any medium, provided the original author and source are credited. 
Citation: Jia-Gen W, Tingting G, Hong-Yuan Z, Yi-Yun X, Xiu-Zhen Z, et al. (2011) Preparation and Optimization of PEG-PLGA Loaded with Vincristine Sulfate and its In vitro Release . J Bioequiv Availab 3: 211-214. doi:10.4172/jbb.1000088

water phase using probe sonication for a while to form the $\mathrm{W} 1 / \mathrm{O} /$ $\mathrm{W} 2$ emulsion. The $\mathrm{W} 1 / \mathrm{O} / \mathrm{W} 2$ emulsion was gently stirred at room temperature in a fume hood until the evaporation of the organic solvent was complete.

The produced nanoparticles were collected by centrifugation $(16000 \mathrm{r} / \mathrm{min})$ at $4^{\circ} \mathrm{C}$ for 1 hour and washed with distilled water, thrice, to remove the emulsifier. The obtained nanoparticle suspension was freeze-dried and kept in a desiccator.

\section{Particle size distribution and zeta potential}

Particle size distribution and zeta potential were determined by Zetasizer 2000. Each sample of nanoparticles preparation was analyzed in duplicate with 30 readings for per nanoparticle sample suspended in distilled water. Figure 1 shows the particle size distribution of the VCR-PEG-PLGA NPs.

\section{Determination of the drug loading capacity of PEG-PLGA- NPs}

The obtained nanoparticle suspension was centrifuged (16000 r/

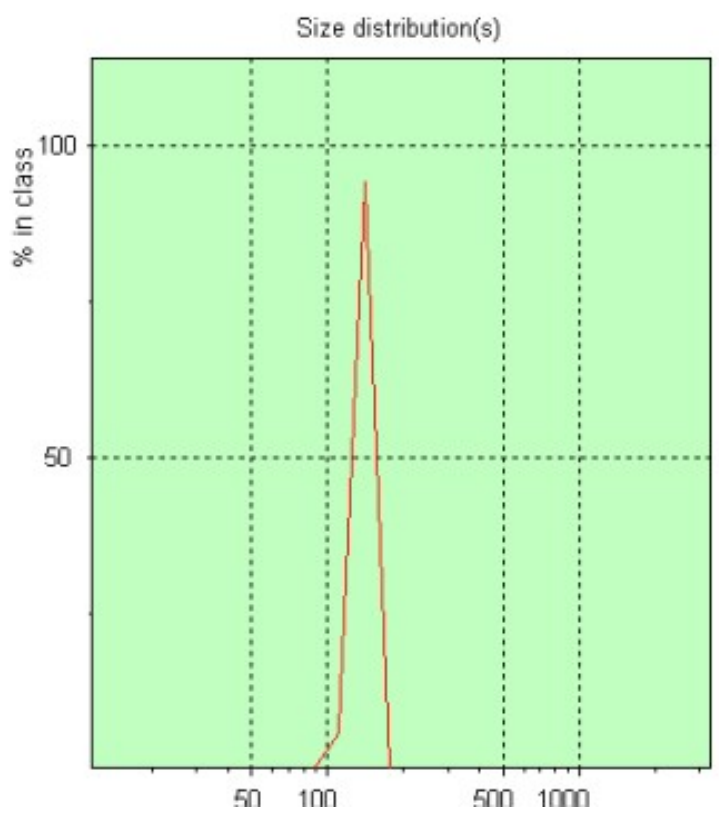

Figure 1: Particle size distribution of VCR-PEG-PLGA NPs.

\begin{tabular}{|l|l|l|l|}
\hline $\begin{array}{l}\text { Copolymer } \\
(\mathrm{mg} / \mathrm{ml})\end{array}$ & $\begin{array}{l}\text { Particle size } \\
(\mathrm{nm})\end{array}$ & $\begin{array}{l}\text { Entrapment efficiency } \\
(\%)\end{array}$ & $\begin{array}{l}\text { Drug loading } \\
(\%)\end{array}$ \\
\hline 5 & 100.8 & 13.3 & 5.05 \\
10 & 121.1 & 32.3 & 6.06 \\
20 & 136.6 & 58.6 & 5.53 \\
40 & 262.3 & 66.3 & 3.21 \\
\hline
\end{tabular}

Table 1: Effect of copolymer concentration on the PEG-PLGA-NPs characteristics.

\begin{tabular}{|l|l|l|l|}
\hline $\begin{array}{l}\text { W1/O } \\
(\mathrm{ml} / \mathrm{ml})\end{array}$ & Particle size $(\mathrm{nm})$ & Entrapment efficiency (\%) & $\begin{array}{l}\text { Drug loading } \\
(\%)\end{array}$ \\
\hline $1 / 10$ & 135.5 & 58.9 & 2.86 \\
$1 / 5$ & 142.7 & 48.4 & 4.06 \\
$3 / 10$ & 112.5 & 42.3 & 5.96 \\
$2 / 5$ & 95.1 & 34.3 & 5.36 \\
\hline
\end{tabular}

Table 2: Effect of internal water phase/oil phase on the PEG-PLGA-NPs characteristics.

\begin{tabular}{|l|l|l|l|}
\hline $\begin{array}{l}\text { W2/O } \\
(\mathrm{ml} / \mathrm{ml})\end{array}$ & $\begin{array}{l}\text { Particle size } \\
(\mathrm{nm})\end{array}$ & $\begin{array}{l}\text { Entrapment efficiency } \\
(\%)\end{array}$ & $\begin{array}{l}\text { Drug loading } \\
(\%)\end{array}$ \\
\hline 2 & 206.6 & 37.2 & 3.61 \\
5 & 210.7 & 42.5 & 4.07 \\
8 & 145.8 & 51.8 & 4.92 \\
10 & 210.2 & 47.2 & 4.50 \\
\hline
\end{tabular}

Table 3: Effect of external water phase/oil phase on the PEG-PLGA-NPs characteristics.

\begin{tabular}{|l|l|l|l|}
\hline Emulsifiers & $\begin{array}{l}\text { Particle size } \\
(\mathrm{nm})\end{array}$ & $\begin{array}{l}\text { Entrapment efficiency } \\
(\%)\end{array}$ & $\begin{array}{l}\text { Drug loading } \\
(\%)\end{array}$ \\
\hline PVA & 154.2 & 35.6 & 3.52 \\
F-68 & 137.3 & 52.8 & 5.01 \\
Twen-80 & 156.8 & 49.2 & 4.69 \\
\hline
\end{tabular}

Table 4: Effect of several emulsifiers on PEG-PLGA-NPs characteristics.

\begin{tabular}{|l|l|l|l|}
\hline $\begin{array}{l}\text { Ultrasound for } \\
\text { first time (s) }\end{array}$ & $\begin{array}{l}\text { Particle size } \\
(\mathrm{nm})\end{array}$ & $\begin{array}{l}\text { Entrapment efficiency } \\
(\%)\end{array}$ & $\begin{array}{l}\text { Drug loading } \\
(\%)\end{array}$ \\
\hline 10 & 198.2 & 44.3 & 4.24 \\
30 & 99.9 & 47.3 & 4.51 \\
60 & 139.1 & 49.3 & 4.70 \\
120 & 105.7 & 46.8 & 4.47 \\
\hline
\end{tabular}

Table 5: Effect of ultrasound for the first time on PEG-PLGA-NPs characteristics.

\begin{tabular}{|l|l|l|l|}
\hline $\begin{array}{l}\text { Ultrasound for } \\
\text { the second time }(\min )\end{array}$ & $\begin{array}{l}\text { Particle size } \\
(\mathrm{nm})\end{array}$ & $\begin{array}{l}\text { Entrapment efficiency } \\
(\%)\end{array}$ & $\begin{array}{l}\text { Drug loading } \\
(\%)\end{array}$ \\
\hline 0.5 & 95.4 & 36.2 & 3.49 \\
1 & 137.3 & 48.2 & 4.59 \\
2 & 141.7 & 40.9 & 3.92 \\
4 & 212.6 & 38.2 & 3.67 \\
& & & \\
\hline
\end{tabular}

Table 6: Effect of ultrasound for the second time on PEG-PLGA-NPs characteristics.

$\min )$ at $4^{\circ} \mathrm{C}$ for $1 \mathrm{~h}$ and then the supernatant was detected using UV at $297 \mathrm{~nm}$ to calculate the drug entrapment efficiency and loading capacity.

\section{In vitro release}

50mg of VCR-loaded PEG-PLGA-NPs dispersed in 5mL of PBS $(\mathrm{pH}=7.4)$ were enclosed in dialysis bags and incubated in $500 \mathrm{ml}$ of PBS ( $\mathrm{pH} 7.4$ ), agitated using the shaker at $120 \mathrm{r} / \mathrm{min}$ at $37^{\circ} \mathrm{C}$. At predetermined time intervals, $5 \mathrm{ml}$ samples were withdrawn and centrifuged for $1 \mathrm{~h}$. The supernatant was assayed and replaced by $5 \mathrm{ml}$ PBS (pH 7.4) immediately after withdrawn. Each nanoparticles batch was analyzed in triplicate.

\section{Results and Discussion}

\section{Single factor}

The factors that may influence the particle size and drug loading capacity of the VCR-loaded-PEG-PLGA-NPs were investigated in the study. The prescription factors include: (1) PEG-PLGA concentration ( $\mathrm{mg} / \mathrm{ml}) ;(2)$ internal water phase/oil phase $(\mathrm{ml} / \mathrm{ml}) ;(3)$ external water phase/oil phase $(\mathrm{ml} / \mathrm{ml})$; (4) the kind of the emulsion $0.5 \%$ : PVA, Tween-80, F-68. The design factors include: (1) ultrasound time for the first time; (2) ultrasound time for the second time; (3) ultrasound power; (4) the method to evaporation the organic phase. The results are showed in Table 1 to Table 8 . The tables show that there are some factors that remarkably influenced the particle size and drug loading of the PEG-PLGA-NPs. The best conditions of the prescription were: (1) copolymer: $10 \mathrm{mg} / \mathrm{ml}$; (2) internal water phase/oil phase: $3: 10$; (3) 
Citation: Jia-Gen W, Tingting G, Hong-Yuan Z, Yi-Yun X, Xiu-Zhen Z, et al. (2011) Preparation and Optimization of PEG-PLGA Loaded with Vincristine Sulfate and its In vitro Release . J Bioequiv Availab 3: 211-214. doi:10.4172/jbb.1000088

external water phase/oil phase: $8: 1$; (4) the emulsifiers: PVA $(0.5 \%)$ while the design conditions were (1) ultrasound 30s for the first time; (2) ultrasound $1 \mathrm{~min}$ for the second time; (3) ultrasound power is $20 \%$; (4) the method to evaporation the organic is $37^{\circ} \mathrm{C}$ rotatory evaporator.

\section{Orthogonal test}

The best preparation conditions were optimized through the orthogonal test according to the results of the single factor study. The orthogonal experimental design method was adopted and $\mathrm{L}_{9}\left(3^{4}\right)$ table was chosen for the experiment as the Table 9 showed. The results of visual analysis and variance analysis are shown in Table 10 and Table 11.

In view of the visual analysis, we can see the factors influence the entrapment efficiency listed in a decreasing order as follows: $A>C>B$ $>\mathrm{D}$ according to the $\mathrm{R}$ value. In the variance analysis we can see that A has s significant different. So the maximum entrapment efficiency and drug loading of the VCR-PEG-PLGA-NPs was obtained when A2B3C1D2 taken (the copolymer concentration: $15 \mathrm{mg} / \mathrm{ml}$, the internal water phase/oil phase: $7 / 20$, external water phase/oil phase: $6: 1$, the ultrasound time for the second time: $1.5 \mathrm{~min}$.).

\section{In vitro release}

The result of in vitro release of VCR from PEG-PLGA-NPs is shown in Figure 2 After an obvious burst release of about 32 VCR in the first 2 hours, a smooth release of VCR can maintain for about 13 days, its cumulative release was up to $81 \%$. Figure 2 . shows that the drug release behavior of PEG-PLGA-NPs was fitted into a Higuchi equation $\mathrm{Q}=3.4670 \mathrm{t}+40.346, \mathrm{R}^{2}=0.9582$.

\section{Conclusions}

In the present investigation, VCR-loaded PEG-PLGA-NPs were commonly prepared by the modified double emulsion method. The physicochemical characteristics of VCR-loaded PEG-PLGA-NPs were

\begin{tabular}{|l|l|l|l|}
\hline $\begin{array}{l}\text { Ultrasound } \\
\text { power }(\%)\end{array}$ & $\begin{array}{l}\text { Particle size } \\
(\mathrm{nm})\end{array}$ & $\begin{array}{l}\text { Entrapment efficiency } \\
(\%)\end{array}$ & $\begin{array}{l}\text { Drug loading } \\
(\%)\end{array}$ \\
\hline 20 & 136.4 & 58.2 & 5.50 \\
40 & 101.8 & 53.3 & 5.06 \\
60 & 159.1 & 47.8 & 4.56 \\
80 & 133.3 & 45.5 & 4.35 \\
\hline
\end{tabular}

Label: (100\% ultrasound power is $250 \mathrm{~W}$ )

Table 7: Effect of ultrasound power on PEG-PLGA-NPs characteristics.

\begin{tabular}{|l|l|l|l|}
\hline Method & $\begin{array}{l}\text { Particle size } \\
(\mathrm{nm})\end{array}$ & $\begin{array}{l}\text { Entrapment efficiency } \\
(\%)\end{array}$ & $\begin{array}{l}\text { Drug loading } \\
(\%)\end{array}$ \\
\hline $\begin{array}{l}\text { magnetic stirring } \\
\left(25^{\circ} \mathrm{C}\right) \\
\text { rotatory } \\
\text { evaporating } \\
\left(25^{\circ} \mathrm{C}\right)\end{array}$ & 172.6 & 47.8 & 4.56 \\
$\begin{array}{l}\text { rotatory evaporator } \\
\left(37^{\circ} \mathrm{C}\right)\end{array}$ & 131.2 & 52.6 & 4.99 \\
\hline
\end{tabular}

Table 8: Effect of the evaporation method on PEG-PLGA-NPs characteristics.

\begin{tabular}{|l|l|l|l|l|}
\hline levels & \multicolumn{5}{|l|}{ Factors } \\
\cline { 2 - 4 } & $\mathrm{A}(\mathrm{mg} / \mathrm{ml})$ & $\mathrm{B}(\mathrm{ml} / \mathrm{ml})$ & $\mathrm{C}(\mathrm{ml} / \mathrm{ml})$ & $\mathrm{D}(\mathrm{min})$ \\
2 & 10 & $1 / 4$ & 6 & 1 \\
2 & 15 & $3 / 10$ & 8 & 1.5 \\
3 & 20 & $7 / 20$ & 10 & 2 \\
\hline
\end{tabular}

Table 9: Factors and levels of L9 (34) orthogonal test.

\begin{tabular}{|l|l|l|l|l|l|l|l|}
\hline Number & A & B & C & D & $\begin{array}{l}\text { Particle } \\
\text { Size } \\
(\mathrm{nm})\end{array}$ & $\begin{array}{l}\text { Entrapment } \\
\text { efficiency } \\
(\%)\end{array}$ & $\begin{array}{l}\text { Drug loading } \\
(\%)\end{array}$ \\
\hline 1 & 10 & $1 / 4$ & 6 & 1 & 98.1 & 48.2 & 6.75 \\
2 & 10 & $3 / 10$ & 8 & 1.5 & 102.2 & 41.4 & 7.64 \\
3 & 10 & $7 / 20$ & 10 & 2 & 107.3 & 43.5 & 8.00 \\
4 & 15 & $1 / 4$ & 8 & 2 & 137.6 & 57.6 & 7.13 \\
5 & 15 & $3 / 10$ & 10 & 1 & 143.5 & 60.3 & 7.44 \\
6 & 15 & $7 / 20$ & 6 & 1.5 & 135.9 & 68.2 & 8.34 \\
7 & 20 & $1 / 4$ & 10 & 1.5 & 115.5 & 61.3 & 5.78 \\
8 & 20 & $3 / 10$ & 6 & 2 & 148.2 & 70.3 & 6.57 \\
9 & 20 & $7 / 20$ & 8 & 1 & 152.2 & 67.8 & 6.35 \\
\hline K1 & 44.367 & 55.700 & 62.233 & 58.767 & & & \\
K2 & 62.033 & 57.333 & 55.600 & 56.967 & & & \\
K3 & 66.467 & 59.833 & 55.033 & 57.133 & & & \\
R & 22.100 & 4.133 & 7.200 & 1.800 & & & \\
\hline
\end{tabular}

Table 10: Visual analysis.

\begin{tabular}{|l|l|l|l|l|l|}
\hline factor & deviance & DOF & F-ratio & F-critical value & significance \\
\hline A & 820.176 & 2 & 3.460 & 3.110 & $*$ \\
\hline B & 26.002 & 2 & 0.110 & 3.110 & \\
\hline C & 96.162 & 2 & 0.406 & 3.110 & \\
\hline D & 5.936 & 2 & 0.025 & 3.110 & \\
\hline error & 948.28 & 8 & & & \\
\hline
\end{tabular}

Table 11: Variance analysis.

\section{Invitro release}

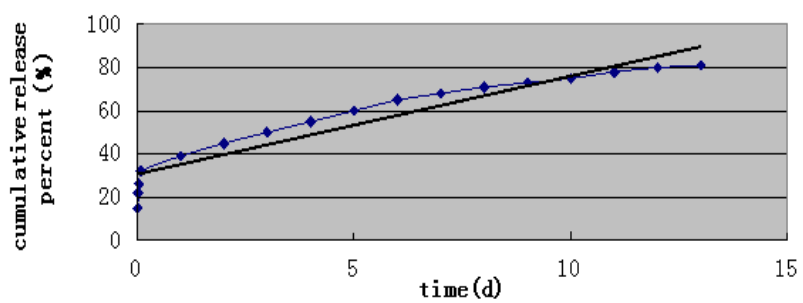

Figure 2: In vitro release of VCR-PEG-PLGA NPs.

affected by polymer concentration, internal water phase/oil phase, external water phase/oil phase and ultrasound time for the second time. VCR-loaded PEG-PLGA-NPs with particle size of $135.9 \mathrm{~nm}$, zeta potential of $-12.83 \mathrm{mV}$, encapsulation efficiency of $68.2 \%$, and drug loading of $8.34 \%$ were prepared under optimal conditions. PEGPLGA-NPs exhibited a sustained in vitro release that lasted for more than 13 days, which fit the Higuchi equation. This could be valuable for preparing drug controlled release systems to satisfy clinical demands. Our experimental results indicated that PEG-PLGA-NPs could be used to develop drug carriers for VCR.

More detailed and exhaustive investigations are needed to fully realize the potential of these drug carriers. The bio-distribution, cellular toxicity, pharmacokinetics, pharmacodynamics of VCR-loaded PEGPLGA-NPs in cells and animal models are currently under investigation in this laboratory.

\section{Acknowledgements}

We thank to National Hi-tech Project of China for financial support ( 2007AA021803, 2007AA021901).

\section{References}

1. Avila J (1997) The use of microtubule poisons on tumour cells. Cancer $\mathrm{J} 10$ 315-318. 
Citation: Jia-Gen W, Tingting G, Hong-Yuan Z, Yi-Yun X, Xiu-Zhen Z, et al. (2011) Preparation and Optimization of PEG-PLGA Loaded with Vincristine Sulfate and its In vitro Release . J Bioequiv Availab 3: 211-214. doi:10.4172/jbb.1000088

2. Sandler SG, Tobin W, Henderson ES (1969) Vincristine-induced neuropathy: A clinical study of fifty leukemic patients. Neurology 19: 367-374.

3. Postma TJ, Benard BA, Huijgens PC, Ossenkoppele GJ, Heimans JJ (1993) Long term effects of vincristine on the peripheral nervous system. J NeuroOnocol 15: 23-27.

4. Lu Y, Hou SX, Chen T (2003) Advances in the study ofvincristine: an anticancer ingredient from Catharanthus roseus. Zhongguo Zhong Yao Za Zhi 28: 10061009.

5. Cecen E, Uysal KM, Ozguven A, Gunes D, Irken G, et al. (2007) Veno-occlusive disease in a child with rhabdomyosarcoma after conventional chemotherapy: report of a case and review of the literature. J Pediatr. Hematol Oncol 24: 615621.

6. Jordan MA, Thrower D, Wilson L (1991) Mechanism of inhibition of cell proliferation by vinca alkaloids. Cancer Res 51: 2212-2222.

7. Lobert S, Vulevic B, Correia JJ (1996) Interaction of vinca alkaloids with tubulin: a comparison of vinblastine, vincristine and vinorelbine. Biochemistry 35 6806-6814.

8. Ambudkar SV, Kimchi-Sarfaty C, Sauna ZE, Gottesman MM (2003) P-glycoprotein from genomics to mechanism. Oncogene 22: 7468-7485.

9. Borst P, Zelcer N, van de Wetering K, Poolman B (2006) On the putative cotransport of drugs by multidrug resistance proteins. FEBS Lett 580: 1085-1093.

10. Marinina J, Shenderova A, Mallery SR, Schwendeman SP (2000) Stabilization of vinca alkaloids encapsulated in poly(lactide-co-glycolide) microspheres. Pharma Res 17: 677-683.

11. Song XR, Zhao Y, Wu WB, Bi YQ, Cai Z, et al. (2008) PLGA nanoparticles simultaneously loaded with vincristine sulfate and verapamil hydrochloride: Systematic study of particle size and drug entrapment efficiency. Int J Pharm 350: 320-329.
12. Lee KS, Chung HC, Im SA, Park YH, Kim CS, et al. (2008) Multicenter phase II trial of Genexol-PM, a Cremophor-free, polymeric micelle formulation of paclitaxel, in patients with metastatic breast cancer. Breast Cancer Res Treat 108: $241-250$.

13. Kim DW, Kim SY, Kim HK, Kim SW, Shin SW, et al. (2007) Multicenter phase I trial of Genexol-PM, a novel Cremophor-free, polymeric micelle formulation of paclitaxel, with cisplatin in patients with advanced non-small-cell lung cancer. Ann Oncol 18: 2009-2014.

14. Kim TY, Kim DW, Chung JY, Shin SG, Kim SC, et al. (2004) Phase I and pharmacokinetic study of Genexol-PM, a cremophor-free, polymeric micelleformulated paclitaxel, in patients with advanced malignancies. Clin Cancer Res 10: 3708-3716.

15. Chan JM, Zhang LF, Yuet KP, Liao G, Rhee JM, et al. (2009) PLGA-lecithinPEG core-shell nanoparticles for controlled drug delivery. Biomaterials 30 1627-1634.

16. Yang AS, Liu W, Yang L, Li ZY, Xu HB, et al. (2007) Tumor necrosis factor alpha blocking peptide loaded PEG-PLGA nanoparticles: Preparation and in vitro evaluation. Int J Pharm 331: 123-132.

17. Vonarbourg A, Passirani C, Saulnier P, Benoit JP (2006) Parameters influencing the stealthiness of colloidal drugdelivery systems. Biomaterials 27: 4356-4373.

18. Song C, Labhasetwar V, Guzman L, Topol E, Levy RJ (1995) Dexamethasonenanoparticles for intra-arterial localisation in restonosis in rats, Proceed. Intern. Symp. Control Rel Bioact Mater 22: 444-445.

19. Molpeceres J, Guzman M, Aberturas MR, Chacon M, Berges L (1996) Application of central composite designs to the preparation of polycaprolactone nanoparticles by solvent isplacement. J Pharm Sci 85: 206-213.

20. Alle'mann E, Leroux JC, Gurny R, Doelker E (1993) In vitro extended release properties of drug-loaded poly(DL-lactic acid) nanoparticles produced by a salting out procedure. Pharm Res 10: 1732-1737. 